\title{
Protein phosphatase 1-dependent transcriptional programs for long-term memory and plasticity
}

\author{
Johannes Gräff, ${ }^{1,4,5}$ Kyoko Koshibu, ${ }^{1,4}$ Anne Jouvenceau, ${ }^{2,3}$ Patrick Dutar, ${ }^{2,3}$ and \\ Isabelle M. Mansuy ${ }^{1,6}$ \\ ${ }^{1}$ Brain Research Institute, Medical Faculty of the University Zürich and Department of Biology of the Swiss Federal Institute of
Technology, CH-8057 Zürich, Switzerland; ${ }^{2}$ INSERM, U549, Paris F-75014, France; ${ }^{3}$ Neurobiologie de la Croissance et de la
Sénescence, Faculté de Médecine René Descartes, Université Paris Descartes, 75014 Paris, France
}

Gene transcription is essential for the establishment and the maintenance of long-term memory (LTM) and for long-lasting forms of synaptic plasticity. The molecular mechanisms that control gene transcription in neuronal cells are complex and recruit multiple signaling pathways in the cytoplasm and the nucleus. Protein kinases (PKs) and phosphatases (PPs) are important players in these mechanisms. Protein serine/threonine phosphatase 1 (PPI), in particular, was recently shown to be important for transcription-dependent memory by regulating chromatin remodeling. However, the impact of PPI on gene transcription in adult neurons remains not fully delineated. Here, we demonstrate that the nuclear pool of PPI is associated with transcriptional events involving molecular components of signaling cascades acting as positive and negative regulators of memory and brain plasticity. The data show that inhibiting this pool selectively in forebrain neurons improves memory performance, enhances long-term potentiation (LTP), and modulates gene transcription. These findings highlight an important role for PP1 in the regulation of gene transcription in LTM and synaptic plasticity in the adult brain.

[Supplemental material is available online at http://www.learnmem.org.]

Memory is a complex process that has several temporal phases, which include short-term memory (STM), lasting minutes to hours, and long-term memory (LTM), lasting hours to days or even years. STM is formed rapidly and involves the recruitment and post-translational modification of already existing proteins such as neurotransmitter receptors and ion channels and a rapid modulation of the efficiency of synaptic transmission. LTM, in contrast, requires de novo synthesis of proteins that is often preceded by an increase in the rate of gene transcription (Kandel and Schwartz 1982; Davis and Squire 1984; Stork and Welzl 1999; Kandel 2001). Thus, STM is thought to be primarily mediated by changes occurring directly at synapses, while LTM requires nuclear processes (Goelet et al. 1986).

Protein kinases (PKs) and phosphatases (PPs) are important mediators of synaptic and nuclear processes that, together, form a molecular balance that controls neuronal signaling and synaptic efficacy (Lisman 1989; Wang and Kelly 1996; Martin et al. 2000; Hedou and Mansuy 2003; Munton et al. 2004; Mansuy and Shenolikar 2006). This balance regulates synaptic transmission and plasticity positively by phosphorylation of specific substrates by PKs and negatively by dephosphorylation of similar and/or additional substrates by PPs. In the soma and nerve terminals, these substrates include synaptic proteins and receptors, while in the nucleus they include signaling molecules and transcription factors, which in turn contribute to gene regulation. In LTM, some of the newly synthesized proteins are ultimately transported to synapses, where they can directly influence synaptic processes

\footnotetext{
${ }^{4}$ These authors contributed equally to this work.

5 Present address: The Picower Institute for Learning and Memory, Department of Brain and Cognitive Sciences, Massachusetts Institute of Technology, Cambridge, MA 02139, USA.

${ }^{6}$ Corresponding author.

E-mail mansuy@hifo.uzh.ch; fax +41 446353303.

Article is online at http://www.learnmem.org/cgi/doi/10.1101/Im.1766510.
}

required for learning and memory (Cohen and Greenberg 2008). To better delineate the molecular mechanisms that engage PKs and PPs, it is important to not only identify the proteins that they control, but also to determine their influence on transcriptional regulation in the nucleus. However, to date, transcriptional regulation by PKs and PPs remains not fully understood, and only a few target genes have been identified. This lack of knowledge is particularly true for PPs, despite the recognition that they are important regulators of gene transcription in LTM (Moorhead et al. 2007; Virshup and Shenolikar 2009).

Protein serine/threonine phosphatase-1 (PP1) is an abundant PP in the brain that exists in four isoforms $(\alpha, \beta, \gamma$, and $\delta)$ differentially expressed in the cytoplasm and the nucleus (Ceulemans and Bollen 2004; Moorhead et al. 2007). While PP1 $\alpha$ is mainly cytoplasmic, PP1 $\beta$ and PP1 $\delta$ are both cytoplasmic and nuclear, and PP1 $\gamma$ is predominantly nuclear. These multiple isoforms have their own set of substrates, depending on their subcellular localization and interacting partners. In the brain, the pool of PP1 present in synaptic terminals is known to negatively regulate neuronal signaling and synaptic strength (Morishita et al. 2001; Jouvenceau et al. 2006). This pool was also shown to act as a molecular constraint on learning and as a memory suppressor (Genoux et al. 2002). The functions of PP1 in the nucleus, in particular in neuronal cells remain, however, unclear.

This study examines the functions of the nuclear pool of PP1 in gene transcription associated with LTM and synaptic plasticity, and investigates the genes that PP1 regulates in the adult mouse brain. It uses a transgenic mouse model in which the nuclear pool of PP1 is selectively inhibited inducibly in hippocampal neurons by the conditional expression of an active nuclear inhibitor of PP1 (NIPP1*). In these mice, the inhibition of nuclear PP1 improves spatial LTM, and facilitates long-term potentiation (LTP) in area CA1 of the hippocampus and the dentate gyrus in a transcription-dependent manner. These improvements are 
associated with the differential expression of 198 annotated genes with varied functions, including intracellular and transmembrane signaling, transcriptional and translational regulation, and control of proteasomal pathways. This study underscores the importance of PP1-dependent pathways in the regulation of LTM, LTP, and gene transcription in forebrain neurons, and reveals some of the genes controlled by PP1.

\section{Results}

\section{Inducible and neuron-specific inhibition of nuclear PPI} in the hippocampus

To study the involvement of PP1 in nuclear events activated during LTM and synaptic plasticity in adult animals, we inhibited the nuclear pool of PP1 selectively in forebrain neurons in vivo. This was achieved by generating transgenic mice that express an active fragment of a nuclear inhibitor of PP1, NIPP1* (Jagiello et al. 2000), in the brain. This fragment carries a nuclear localization signal and a PP1 inhibition domain, but excludes the RNA binding and splicing domains of NIPP1. NIPP1* and a LacZ reporter gene were coexpressed inducibly and reversibly using a bidirectional tetO promoter and the doxycycline (dox)-dependent reverse tetracycline-controlled transactivator (rtTA2) system (Michalon et al. 2005) under the control of the $\mathrm{Ca}^{2+} / \mathrm{CaM}$ dependent protein kinase II $\alpha$ (CaMKII $\alpha)$ promoter (Fig. 1A). In the resulting double transgenic mice, NIPP1* and LacZ expression was abundant in the hippocampal formation (hippocampus area $\mathrm{CA} 1$ and dentate gyrus), only marginally present in the amygdala (Fig. 1B; Fig. 3A,B; Supplemental Fig. 1A), but not detected in non-forebrain structures such as the hypothalamus, consistent with the forebrain specificity of the CaMKII $\alpha$ promoter (Mayford et al. 1996). Further, transgene expression was not induced in the absence of dox, confirming its dox dependence (Fig. 1B, right). At a subcellular level, NIPP1* expression was restricted to the nucleus of neuronal cells (Supplemental Fig. 1B,C). Biochemically, NIPP1* expression led to a significant decrease in PP1 activity in nuclear extracts from the hippocampus, but had no effect in cytoplasmic extracts (Fig. 1C). Further, total serine/threonine phosphatase activity determined with RII phosphopeptide as a substrate was similar in control and NIPP1* transgenic animals in all assays conducted (data not shown). Finally, phosphatase inhibition was specific to PP1 and did not involve PP2A, a structurally related PP (Supplemental Fig. 1D).

\section{Inhibition of nuclear PP1 enhances hippocampus-dependent spatial memory}

Since NIPP1* expression was most abundant in the hippocampal formation, we examined spatial memory in the transgenic mice using a water maze. We observed that the acquisition of a visible version of the task was comparable in transgenic mice and control littermates (Fig. 2A, left). Likewise, the acquisition of a hidden version of the task was comparable, and both groups showed a steady decrease in the latency to reach the hidden platform (Fig. 2A, right). However, when tested for their memory for the platform on a probe trial $1 \mathrm{~d}$ after the end of training, the transgenic mice showed improved performance. Their search for the platform was increased and more precise in the correct quadrant of the maze and the mice spent more time in the correct quadrant and did more platform crossings (Fig. 2B). The memory improvement was a direct effect of NIPP1* expression and was not due to secondary effects, since it was blocked by suppression of NIPP1* expression by dox removal (on/off, Fig. 2C). It was also not due to any change in overall exploratory behavior, since total movement, time spent in center, and rearing behavior in an open field

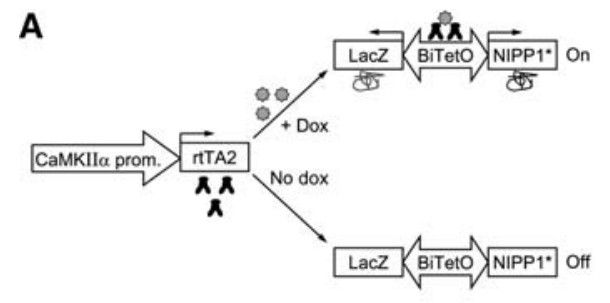

B
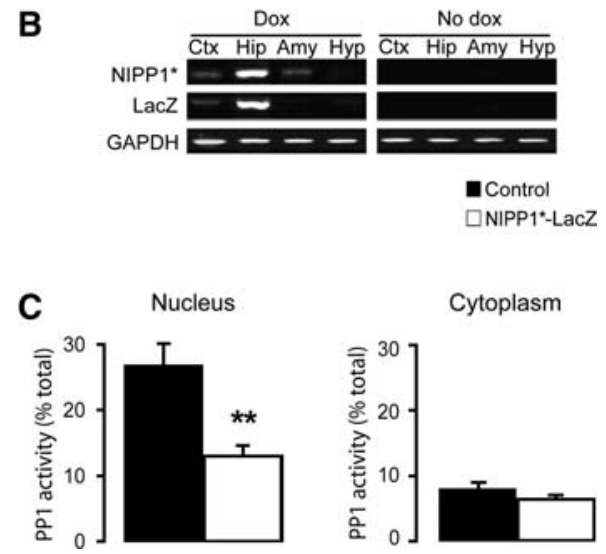

Figure 1. Inducible and neuron-specific inhibition of nuclear PP1 in the adult mouse forebrain. (A) Scheme of the transgenes used to express NIPP1* inducibly in forebrain neurons. NIPP1* and LacZ expression are induced by doxycycline (Dox, On). (B) Reverse transcription polymerase chain reaction (RT-PCR) examining NIPP1* and LacZ expression in cortex (Ctx), hippocampal formation (Hip), amygdala (Amy), and hypothalamus (Hyp) in adult mutant mice treated and not treated with dox. (C) PP1 activity assay in nuclear $(n=7)$ and cytoplasmic $(n=5)$ hippocampal extracts from NIPP1*-LacZ mice and control littermates (nuclear, $n=4$; cytoplasmic, $n=6$ ). Nuclear PP1 activity, $F_{(1,9)}=15.09, P=0.01$; cytoplasmic activity, n.s.

were similar in transgenic mice and control littermates (Fig. 2D). The improvement was also specific to hippocampus-dependent memory since cued fear memory, another form of memory that depends on the amygdala rather than the hippocampus, was not altered (data not shown).

\section{Synaptic plasticity is facilitated by inhibition of nuclear PP1 in a transcription-dependent manner}

LTM has been associated with long-lasting forms of synaptic plasticity and, in particular, with transcription-dependent LTP (Martin et al. 2000; Morris et al. 2003). We examined whether the inhibition of nuclear PP1 in the NIPP1* mice affects LTP in the hippocampal formation by performing in vitro LTP recordings in acute hippocampal slices. LTP was significantly increased in hippocampus area CA1 and the dentate gyrus in transgenic slices (Fig. 3A-D). The increase was apparent in a later phase of LTP in area CA1, but was present immediately after stimulation in the dentate gyrus, suggesting the potential involvement of different mechanisms. Importantly, however, the LTP enhancement most likely did not result from an alteration in basal synaptic transmission since input-output and paired pulse responses were normal in both the hippocampus and dentate gyrus in the transgenic mice (Supplemental Fig. 2). Further, the increase in synaptic efficacy was specific to the stimulated pathway since it was not observed in an adjacent nonstimulated pathway (Supplemental Fig. 3A).

Since nuclear PP1 is involved in transcriptional regulation (Bollen and Beullens 2002; Ceulemans and Bollen 2004; Bennett 
A Water maze - Training

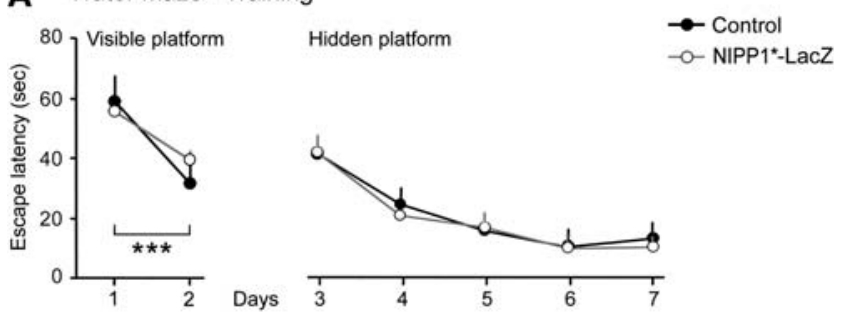

B Spatial memory
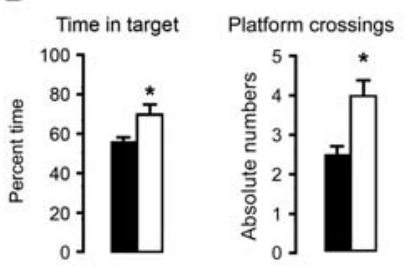

\section{On/off}
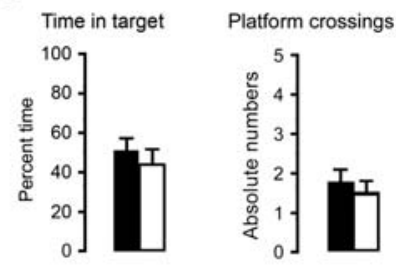

\section{Open field}
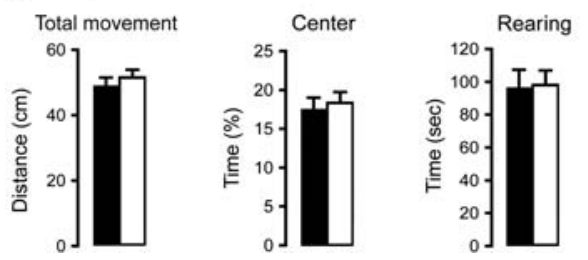

Control

$\square$ NIPP1*-LacZ

Figure 2. Nuclear inhibition of PP1 improves spatial memory in the water maze. (A) Mean escape latency each day during training with a visible platform (left) and acquisition with a hidden platform (right) on the water maze. During training on the visible or hidden platform, animals from both groups had similar performance (Control, $n=9$, NIPP1 ${ }^{*}$-LacZ, $\quad n=6 ; \quad$ visible platform: $\quad F_{(1,28)}=26.22, \quad P<0.001$ between days 1 and 2; hidden platform, n.s. between groups for all days). (B) Percent of total time spent in target quadrant and platform crossings during testing $1 \mathrm{~d}$ after the end of training. NIPP1*-LacZ mice spent more time in the target quadrant and had increased platform crossings compared with control littermates. Percent time spent: $F_{(1,13)}=5.22, P<0.05$; platform crossings: $F_{(1,13)}=7.61, P<0.05$. (C) Percent of total time spent in target quadrant and platform crossings during testing $1 \mathrm{~d}$ after the end of training was similar in NIPP1*-LacZ mice $(n=4)$ and their control littermates $(n=5)$ on/off dox. (D) Total movement, time spent in center, and time spent rearing were similar in control $(n=9)$ and NIPP1 ${ }^{*}$-LacZ mice on dox $(n=6)$ in an open field (all measurements, n.s.).

2005; Moorhead et al. 2007), we next examined whether the increase in LTP depends on transcription using the transcriptional inhibitor actinomycin D. Preincubation of the slices with actinomycin D abolished the increase in LTP in both area CA1 and dentate gyrus (Fig. 3E,F), suggesting the involvement of transcriptional mechanisms. Consistently, a form of LTP induced with 3train of high-frequency stimulation that depends on gene transcription (Huang and Kandel 1994) was not changed in transgenic slices (Supplemental Fig. 3B). Finally, synaptic plasticity induced by low-frequency stimulation $(2$ or $5 \mathrm{~Hz}$ ) was not altered by NIPP1* expression (Supplemental Fig. 3C,D), indicating no influence of nuclear PP1 on this form of plasticity.

\section{Inhibition of nuclear PPI alters the expression of several molecular pathways}

Since transcriptional processes are known to underlie LTM (Kandel and Schwartz 1982; Davis and Squire 1984; Stork and Welzl 1999; Kandel 2001; Alberini 2009) and LTP was facilitated in a transcription-dependent manner by NIPP1* expression, we examined the transcriptional profile of the hippocampus in the transgenic mice. Using genome-wide DNA microarrays, we found that 198 genes were differentially expressed as a result of the inhibition of nuclear PP1. Among these genes, 95 were upregulated and 103 were down-regulated. The genes were identified (with GenBank accession numbers) and, based on geneontology analyses, categorized in classes covering diverse cellular functions, including intra- and intercellular signaling and communication, transmembrane signaling, gene transcription and translation, metabolism, and protein degradation and processing (Fig. 4A). The best-represented class was that of components of intracellular signaling (including calcium-signaling cascades). Among the genes identified, several have already been shown to be involved in memory processes, for instance, the dual specificity phosphatase 16 (DUSP16), neural cell adhesion molecule 1
A

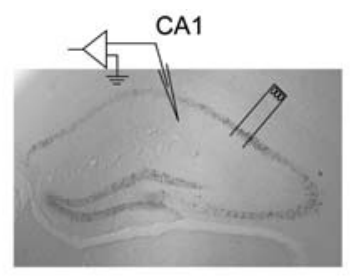

C
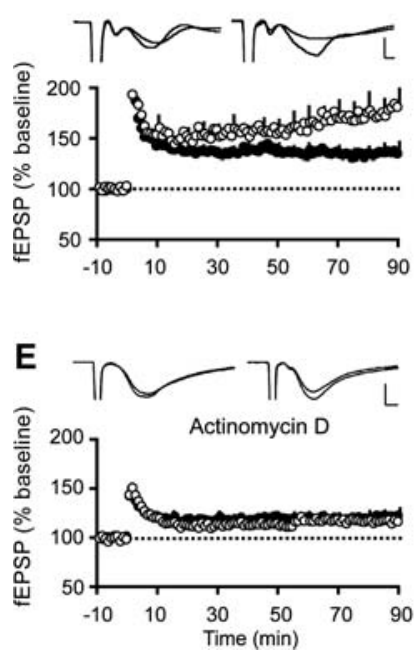

B

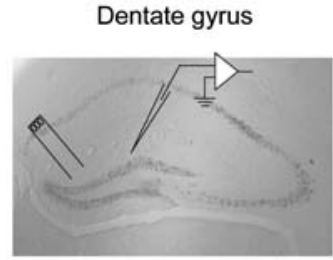

D
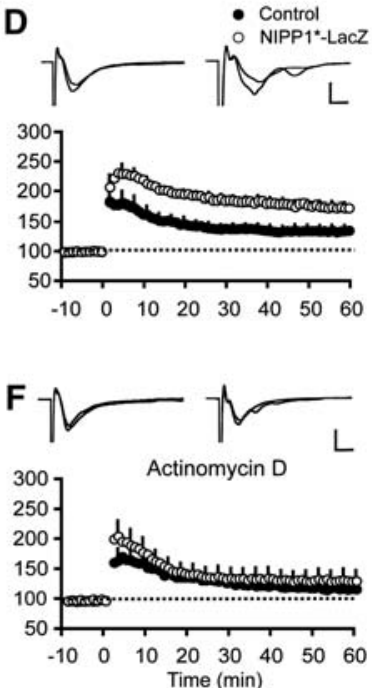

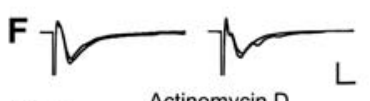

Figure 3. LTP is increased in the hippocampal formation in a transcription-dependent manner. Sagittal sections of adult hippocampus showing NIPP1*-LacZ expression ( $\beta$-Gal immunostaining, dark gray signal) and stimulation and recording electrodes in $(A)$ hippocampus area CA1 and $(B)$ dentate gyrus. LTP in area CA1 in slices from NIPP1*-LacZ mice and control littermates (C) without actinomycin D (NIPP1*-LacZ, $n=8$; Control, $n=12$ ) or $(E)$ with actinomycin D (NIPP1*-LacZ, $n=10$; Control, $n=7) . F_{(3,36)}=9.25, P<0.001$; Tukey post hoc for control versus NIPP1*-LacZ, n.s.; for control versus NIPP1*-LacZ with actinomycin D, n.s.; effect of actinomycin $D$ on control slices, n.s.; effect of actinomycin D on NIPP1*-LacZ slices, $P<0.001$. LTP in dentate gyrus in slices from NIPP $1^{*}$-LacZ mice and control littermates $(D)$ without (NIPP1 ${ }^{*}$-LacZ, $n=15$; Control, $n=14$ ) or $(F)$ with actinomycin D (NIPP1*-LacZ, $n=9$; Control, $n=6$ ). $F_{(3,43)}=4.94, P<0.001$; LSD post hoc, control versus NIPP1*-LacZ slices, $P<0.05$; actinomycin D-treated control versus actinomycin D-treated NIPP1*-LacZ slices, n.s.; control versus actinomycin D-treated control slices, n.s.; NIPP1*-LacZ versus actinomycin D-treated NIPP $1 *$-LacZ slices, $P<0.05$. Representative traces before and after LTP are shown above all graphs for mutant (right) and control (left) slices (scale, $0.5 \mathrm{mV}$ over $5 \mathrm{msec}$ ). 
A

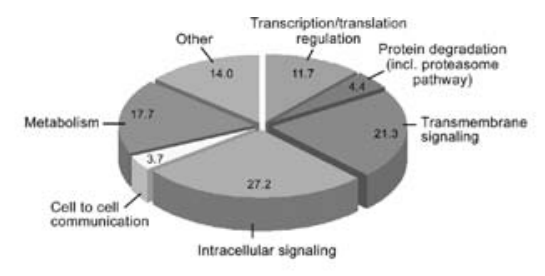

B

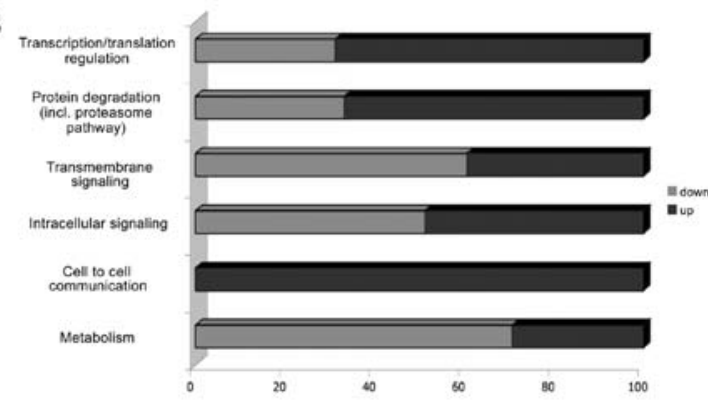

C

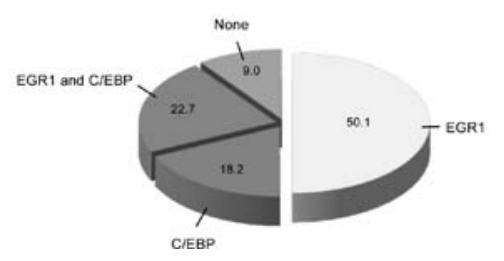

Figure 4. Identification and characterization of differentially expressed genes upon inhibition of nuclear PP1. (A) Diagram representing the functional categories of genes differentially expressed in the hippocampus in NIPP1*-lacZ mice compared with control littermates. Classification is based on functional annotations after Ingenuity pathway analysis. The false discovery rate was 0.14 . Numbers represent percent of total genes differentially expressed. (B) Bar graph showing the percentage of genes up- or down-regulated in each class. (C) Diagram representing the percentage of genes containing putative binding sites for one, both, or none of the transcription factors EGR1 and C/EBP.

(NCAM1), and the transcription factor SP4. Most functional pathways showed bidirectional changes in gene expression, and some of their components were increased, while others were decreased (Fig. 4B). For instance, members of the proteasome pathway such as proteasome-associated peptidases were up-regulated, but proteasome subunits were significantly down-regulated (Table 1). However, some pathways such as gene transcription/translation, protein degradation, or cell-to-cell communication were overall increased, while pathways such as transmembrane signaling and metabolism were overall decreased (Fig. 4B).

To further investigate the transcriptional changes induced by NIPP1*, we analyzed whether putative binding sites for transcription factors known to be important for synaptic plasticity and memory formation were present in the $5^{\prime}$ promoter region of the genes differentially expressed in the transgenic mice. We used the commercially available software program MatInspector (Cartharius et al. 2005) and focused on sequences $1 \mathrm{~kb}$ upstream of the transcriptional start site. We found that each of the differentially expressed genes contained between 100 and 150 putative transcription factor binding sites (data not shown). To verify that these elements were specific to these genes, we deducted all regulatory elements present in the upstream region of the housekeeping genes $\beta$-actin, GAPDH, and $\beta$-tubulin (the expression of which was not altered in the NIPP1* transgenic mice) from the list of putative regulatory elements. Following this normalization step, we found that $50 \%$ of the differentially expressed genes in the mutant mice contained an EGR1-binding site and 18\% contained a C/EBP-binding site. Interestingly, 22\% thereof contained regulatory elements pertaining to both EGR1 and C/EBP (Fig. 4C), which have both been implicated in memory formation (Jones et al. 2001; Guan et al. 2002). Although the upstream region of many PP1-associated genes with altered mRNA expression also contained putative binding sites for other transcription factors important for memory and plasticity, we found that none of them were significantly enriched by our criteria. Hence, these data suggest that PP1 might regulate the candidate genes by so far unknown mechanisms involving EGR1 and C/EBP.

Finally, to confirm the microarray results, we quantified the level of expression of several candidate genes by real-time quantitative PCR (qRT-PCR). These analyses showed overall similar changes in gene expression whether genes were up- or downregulated, providing a good validation of this data (Fig. 5).

\section{Discussion}

This study examines the contribution of the nuclear pool of the protein phosphatase PP1 to the mechanisms of LTM and LTP in the adult brain. It uses a transgenic mouse model in which PP1 can be specifically inhibited inducibly in hippocampal neurons by conditional expression of a specific inhibitor of nuclear PP1. The results show that the inhibition of nuclear PP1 improves hippocampus-dependent LTM and facilitates LTP in a transcription-dependent fashion in area CA1 and the dentate gyrus. They also show that PP1 inhibition is associated with an up- or downregulation of a panel of genes involved in different cellular functions, some of which are relevant for memory formation and synaptic plasticity.

Previous studies have demonstrated that PP1 is a potent memory suppressor in adult mice (Genoux et al. 2002) and a negative regulator of synaptic strength and synaptic plasticity in the hippocampus (Morishita et al. 2001; Jouvenceau et al. 2006; Hedou et al. 2008). These functions of PP1 have been postulated to be mediated primarily by the cytoplasmic pool of PP1, in particular, by PP1 in synaptic terminals. There, PP1 is thought to modulate the phosphorylation of cytoplasmic and membrane targets such as CaMKII and $\alpha$-amino-3-hydroxy-5-methyl-4-isoxazolepropionic acid (AMPA) receptors (Morishita et al. 2001; Genoux et al. 2002; Terry-Lorenzo et al. 2005; Hu et al. 2007; States et al. 2008). The present results provide new evidence that PP1 is also acting in the nucleus and plays a critical role in these functions by regulating gene transcription. In the hippocampus, PP1-regulated gene transcription is important for synaptic plasticity, and its modulation by relief of PP1-dependent control increases LTP. The present results further suggest that the neuronal pool of nuclear PP1 in excitatory neurons is sufficient to fulfill these functions. These findings significantly extend previous data showing that PKs are important for transcriptional events associated with LTM and LTP (Moorhead et al. 2007; Lee and Silva 2009) and highlight the equal importance of PPs in these events through new in vitro and in vivo data.

The present findings show that gene expression is modulated bidirectionally by nuclear PP1, and that the expression of a comparable number of genes is up- or down-regulated by its inhibition. This underscores the role for PP1 in both the repression and the activation of gene transcription. Such a dual role is consistent with the view that there exist positive and negative modulators of memory and plasticity, which act in concert but in opposite directions in the adult brain. However, the data newly suggests that a single protein can be both, which is an important extension of the model. 
Table 1. List of differentially expressed genes with a potential implication in memory and synaptic plasticity in the hippocampal formation of NIPP1*-transgenic mice

\begin{tabular}{|c|c|c|c|c|}
\hline $\begin{array}{l}\text { Gene } \\
\text { symbol }\end{array}$ & Name & $\begin{array}{l}\text { Fold } \\
\text { change }\end{array}$ & Function & Description \\
\hline DUSP-16 & $\begin{array}{l}\text { Dual specificity } \\
\text { phosphatase } 16\end{array}$ & 2.34 & $\begin{array}{c}\text { Intracellular } \\
\text { signaling }\end{array}$ & Inhibitor of MAPK activity \\
\hline FOLH1 & Folate hydrolase & 1.75 & $\begin{array}{l}\text { Intracellular } \\
\text { signaling }\end{array}$ & $\begin{array}{l}\text { Activator of excitatory } \\
\text { neurotransmission }\end{array}$ \\
\hline UBE2N & $\begin{array}{l}\text { Ubiquitin-conjugating } \\
\text { enzyme E2N }\end{array}$ & 1.52 & $\begin{array}{l}\text { Protein } \\
\text { degradation }\end{array}$ & $\begin{array}{l}\text { Proteasome-associated } \\
\text { peptidase }\end{array}$ \\
\hline IQGAP1 & $\begin{array}{l}\text { IQ motif containing } \\
\text { GTPase activating } \\
\text { protein } 1\end{array}$ & 1.50 & $\begin{array}{l}\text { Cell-to-cell } \\
\text { communication }\end{array}$ & $\begin{array}{l}\text { Promoter of neurite } \\
\text { outgrowth }\end{array}$ \\
\hline USP38 & $\begin{array}{l}\text { Ubiquitin-specific } \\
\text { peptidase } 38\end{array}$ & 1.44 & $\begin{array}{l}\text { Protein } \\
\text { degradation }\end{array}$ & $\begin{array}{l}\text { Proteasome-associated } \\
\text { peptidase }\end{array}$ \\
\hline MSLN & Mesothelin & 1.34 & $\begin{array}{l}\text { Cell-to-cell } \\
\text { communication }\end{array}$ & Cell adhesion molecule \\
\hline SP4 & Sp4 transcription factor & 1.31 & $\begin{array}{l}\text { Transcription } \\
\text { regulator }\end{array}$ & $\begin{array}{l}\text { Dendritic outgrowth } \\
\text { agonist }\end{array}$ \\
\hline ZFP329 & Zinc finger protein 3 & 1.24 & $\begin{array}{l}\text { Transcription } \\
\text { regulator }\end{array}$ & Activator of transcription \\
\hline$M A Z$ & $\begin{array}{l}\text { MYC-associated zinc } \\
\text { finger protein }\end{array}$ & 1.24 & $\begin{array}{l}\text { Transcription } \\
\text { regulator }\end{array}$ & Activator of transcription \\
\hline USP13 & $\begin{array}{l}\text { Ubiquitin-specific } \\
\text { peptidase } 13\end{array}$ & 1.22 & $\begin{array}{l}\text { Protein } \\
\text { degradation }\end{array}$ & $\begin{array}{l}\text { Proteasome-associated } \\
\text { peptidase }\end{array}$ \\
\hline$D D \times 19 B$ & $\begin{array}{l}\text { DEAD box polypeptide } \\
19 \mathrm{~b}\end{array}$ & 1.21 & $\begin{array}{l}\text { Transcription } \\
\text { regulator }\end{array}$ & $\begin{array}{l}\text { Member of splicing } \\
\text { machinery }\end{array}$ \\
\hline NCAM1 & $\begin{array}{l}\text { Neural cell adhesion } \\
\text { molecule } 1\end{array}$ & 1.21 & $\begin{array}{l}\text { Transmembrane } \\
\text { signaling }\end{array}$ & Growth factor receptor \\
\hline CNOT4 & $\begin{array}{l}\text { CCR4-Not transcription } \\
\text { complex, subunit } 4\end{array}$ & -1.20 & $\begin{array}{l}\text { Transcription } \\
\text { regulator }\end{array}$ & Repressor of transcription \\
\hline PSMB9 & $\begin{array}{l}\text { Proteasome subunit, } \beta \\
\text { type, } 9\end{array}$ & -1.25 & $\begin{array}{l}\text { Protein } \\
\text { degradation }\end{array}$ & Proteasome subunit \\
\hline$B A Z 2 A$ & $\begin{array}{l}\text { Bromodomain adjacent } \\
\text { to zinc finger } \\
\text { domain, } 2 \mathrm{~A}\end{array}$ & -1.25 & $\begin{array}{l}\text { Transcription } \\
\text { regulator }\end{array}$ & Histone deacetylase \\
\hline$Z F X$ & $\begin{array}{l}\text { Zinc finger protein } \\
\text { X-linked }\end{array}$ & -1.28 & $\begin{array}{l}\text { Transcription } \\
\text { regulator }\end{array}$ & Activator of transcription \\
\hline SNTB2 & Syntrophin, $\beta 2$ & -1.33 & $\begin{array}{l}\text { Intracellular } \\
\text { signaling }\end{array}$ & Calcium binding \\
\hline TRPC5 & $\begin{array}{l}\text { Transient receptor } \\
\text { cation channel, } \\
\text { subfamily C, } \\
\text { member } 5\end{array}$ & -1.35 & $\begin{array}{l}\text { Transmembrane } \\
\text { signaling }\end{array}$ & $\begin{array}{l}\text { Calcium-dependent cation } \\
\text { channel }\end{array}$ \\
\hline PDE7A & Phosphodiesterase 7A & -1.41 & $\begin{array}{l}\text { Intracellular } \\
\text { signaling }\end{array}$ & $\begin{array}{l}\text { Regulator of cyclic } \\
\text { nucleotides }\end{array}$ \\
\hline ASB11 & $\begin{array}{l}\text { Ankyrin repeat and } \\
\text { SOCS } \\
\text { box-containing } \\
\text { protein } 11\end{array}$ & -1.48 & $\begin{array}{l}\text { Protein } \\
\text { degradation }\end{array}$ & $\begin{array}{l}\text { Activator of ubiquitin } \\
\text { transferase system }\end{array}$ \\
\hline TRPM3 & $\begin{array}{l}\text { Transient receptor } \\
\text { potential cation } \\
\text { channel, subfamily } \\
\text { M, member } 3\end{array}$ & -1.65 & $\begin{array}{l}\text { Transmembrane } \\
\text { signaling }\end{array}$ & Cation channel \\
\hline SNF1LK & SNF1-like kinase & -2.02 & $\begin{array}{l}\text { Intracellular } \\
\text { signaling }\end{array}$ & Inhibitor of CREB activity \\
\hline
\end{tabular}

CCR4, carbon catabolite repression 4-like; CREB, CAMP-responsive element-binding protein; DEAD, aspartate-glutamate-alanine-aspartate; GTP, guanosine triphosphate; MAPK, mitogen-activated protein kinase; MYC, myelocytomatosis oncogene; SNF, sucrose nonfermenting; SOCS, suppressors of cytokine signaling.

Our microarray data show that the transcriptional program regulated by PP1 includes several functional categories relevant for LTM and brain plasticity. For instance, intra- and extracellular signaling molecules involving protein kinases/phosphatases and cellular adhesion molecules are known to be up-regulated in the hippocampus in rats and mice after training on a water maze (Cavallaro et al. 2002) or in a passive avoidance task (D'Agata and Cavallaro 2003). NCAM1, the expression of which is increased by about $20 \%$ by PP1 inhibition, is an adhesion molecule essential for cell-to-cell interaction, neurite outgrowth, and cell migration. It is up-regulated in the hippocampus after spatial learning (Welzl and Stork 2003; Aonurm-Helm et al. 2008) and its deficiency impairs spatial and fear memory (Kaltschmidt et al. 2006; Aonurm-Helm et al. 2008) as well as LTP in the hippocampus (Doherty et al. 1995; Kaltschmidt et al. 2006). NCAM1 was reported to form complexes with PP1 in vitro (Buttner et al. 2005), but its regulation by PP1 in relation with improved LTM was not known before.

Further to NCAM1, several components of protein degradation pathways were differentially regulated by inhibition of nuclear PP1. In total, $4 \%$ of the altered genes are implicated in the proteasome pathway. In the brain this ubiquitous pathway contributes to the mechanisms of memory formation (Bingol and Schuman 2005) and is modulated in mouse models with enhanced learning and memory (Hata et al. 2001; Chen et al. 2003). It is also involved in the induction and the maintenance of long-lasting forms of LTP, most likely by promoting the clearance of proteins from pre- and postsynaptic terminals (Bingol and Schuman 2005) in balance with de novo protein synthesis (Fonseca et al. 2006). In our transgenic model the proteasome-associated peptidase ubiquitin specific protease 13 (USP13) was up-regulated by over $50 \%$. This increase is in line with the reported down-regulation of USP7, a structurally highly similar peptidase, in a mouse model with learning disability and spatial memory deficits (D'Agata et al. 2002). Our data suggest, thus, that USPs might constitute important components of pathways downstream from PP1 involved in memory formation.

Another interesting candidate is the transcription factor SP4, the expression of which was increased by $30 \%$ in the NIPP1* mice. SP4 regulates dendritic growth (Ramos et al. 2007) and the expression of neurotrophins during development (Ishimaru et al. 2007). It also activates the expression of $\gamma$-aminobutyric acid (GABA) receptors (Ma et al. 2004), which mediate inhibitory neurotransmission during memory formation (Paulsen and Moser 1998). Further, Sp4 deficiency in knock-out mice severely disrupts contextual fear memory (Zhou et al. 2005) and reduces dendritic growth and arborization in the hippocampus (Zhou et al. 2007). Sp4 itself is increased in the hippocampus following contextual fear conditioning (Fischer et al. 2003) and may raise the level of cyclindependent kinase 5 (Cdk5), an important regulator of structural plasticity (Dhavan and Tsai 2001).

Overall, the transcriptional changes identified in the hippocampus in this study are significant, but modest. This may be because nuclear PP1 is inhibited only in excitatory neurons and 


\begin{tabular}{|c|c|c|c|c|}
\hline \multirow[t]{2}{*}{ Gene } & \multicolumn{2}{|c|}{ Microarray analysis } & \multicolumn{2}{|l|}{ qRT-PCR } \\
\hline & $\begin{array}{l}\text { Fold change } \\
\text { versus control }\end{array}$ & Significance & $\begin{array}{l}\text { Fold change } \\
\text { versus control }\end{array}$ & Significance \\
\hline DUSP16 & $2.34 \pm 0.07$ & 0.05 & $2.69 \pm 0.36$ & 0.01 \\
\hline FOLH1 & $1.75 \pm 0.05$ & 0.05 & $1.98 \pm 0.31$ & 0.05 \\
\hline NCAM1 & $1.21 \pm 0.03$ & 0.05 & $1.74 \pm 0.11$ & 0.01 \\
\hline PSMBS & $-1.25 \pm 0.05$ & 0.05 & $-1.54 \pm 0.08$ & 0.01 \\
\hline TRPM3 & $-1.65 \pm 0.08$ & 0.05 & $-1.92 \pm 0.07$ & 0.01 \\
\hline SNF1LK & $-2.02 \pm 0.18$ & 0.05 & $-2.27 \pm 0.15$ & 0.05 \\
\hline
\end{tabular}

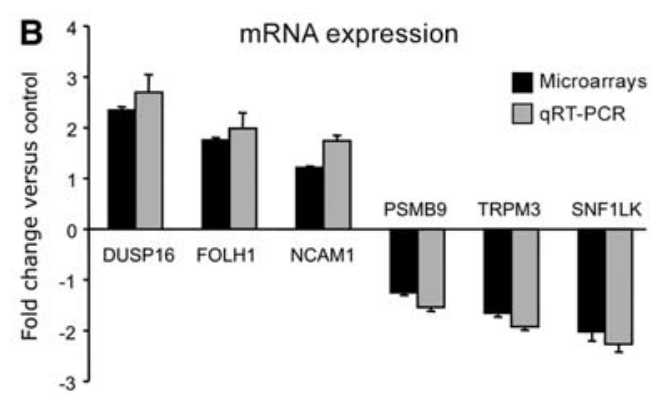

Figure 5. Confirmation of microarray results by qRT-PCR. (A) Comparative evaluation of the change in expression of six selected genes (three up-regulated, three down-regulated) by DNA microarray analyses and qRT-PCR, including $P$-values. (B) Relative fold change in gene expression ( \pm SEM) of the selected genes measured by microarrays and QRT-PCR in NIPP1* mice versus control littermates.

not in inhibitory neurons or in glia cells, owing to the specificity of the CaMKII promoter driving NIPP1* expression (Mayford et al. 1996). Since DNA microarrays were conducted on the whole hippocampal formation, the impact of PP1 inhibition on gene expression is likely to appear diluted. This suggests that the observed transcriptional changes are probably more pronounced in each individual neuron than that measured in the whole tissue. Nonetheless, it is important to note that the total number of genes found to be differentially expressed is consistent with that reported in other studies examining gene expression changes in whole brain areas (Renthal et al. 2007, 2009).

An intriguing finding of the present study is that an immediate phase of LTP was increased by NIPP1* expression in the dentate gyrus, but not in area CA1. This difference may result from differential changes in the expression of distinct genes by NIPP1* in these two hippocampal subfields. For instance, SP4 and NCAM1 are two potential candidates with altered transcription levels by NIPP1* expression. Sp4 is a transcription factor, the deficiency of which, in mice, selectively decreases neuronal cell density in the dentate granule layer and results in a smaller dentate gyrus, but has no negative effect in area CA1 or CA3 (Zhou et al. 2007). Further, NCAM1 is an adhesion molecule expressed more abundantly in the dentate gyrus than in area CA1 (Venero et al. 2002), and which is up-regulated in the hippocampus after spatial learning (Welzl and Stork 2003; Aonurm-Helm et al. 2008). NCAM1 deficiency impairs spatial and fear memory (Kaltschmidt et al. 2006; Aonurm-Helm et al. 2008) and decreases LTP in the hippocampus (Doherty et al. 1995; Kaltschmidt et al. 2006). The increased expression of SP4 and NCAM1 in the transgenic mice may thus contribute to the observed difference in the time course of the LTP enhancement in area CA1 and the dentate gyrus. Another possibility may be that the effect on LTP results from the different level of NIPP1* expression in CA1 compared with dentate gyrus in the transgenic mice. This may differentially affect PP1-dependent molecular pathways underlying LTP in the two hippocampal subfields. Finally, the difference could also be due to the fact that LTP recordings were performed in the presence of the GABA receptor blocker bicuculline in the dentate gyrus and not in area CA1 in order to avoid excessive recurrent collateral inhibition. Such inhibition may favor short-term plasticity in the transgenic mice and explain the increase in the early phase of LTP in the dentate. It should be noted that the rapid inhibitory effect of actinomycin D on LTP in both area CA1 and the dentate gyrus in control slices may result from the fact that the drug was applied for several hours before recording, which may interfere with some components of the induction of LTP.

The mechanisms of action of nuclear PP1 in the regulation of gene expression are not fully understood at this point, but may involve the modulation of transcription factors and regulators in the promoter region of specific target genes (Moorhead et al. 2007). Bioinformatic analyses of putative transcription factor binding sites upstream of the transcriptional start site of differentially expressed genes revealed that EGR1 and C/EBP might be involved. Binding sites for EGR1 and C/EBP were identified in over $90 \%$ of the altered genes, and more than $20 \%$ of these genes harbor both EGR1 and C/EBP sites. EGR1 and C/EBP are important for memory formation, in particular for LTM (Jones et al. 2001; Guan et al. 2002). Both are also targets of phosphorylated CREB (for review, see Lee and Silva 2009), which is a substrate of PP1 (Genoux et al. 2002). Interestingly, in the NIPP1* mice, no change in the level of phosphorylated CREB was detected (data not shown) (see Koshibu et al. 2009), suggesting the possibility for a CREB-independent regulation of EGR1 and C/EBP by PP1. More refined analyses using CREB loss-of-function and PP1 inhibition could help clarify this possibility. Finally, nuclear PP1 is also likely to regulate gene expression via chromatin remodeling (Koshibu et al. 2009), a possibility that is currently under investigation for the genes identified in this study.

In summary, this study newly defines a critical role of nuclear PP1 in the control of transcriptional events important for memory formation and synaptic plasticity in the adult brain.

\section{Materials and Methods}

\section{Animals}

Transgenic mice carrying a fragment including amino acids 143224 of the nuclear inhibitor of PP1 (NIPP1*) linked to a bidirectional tetO (BiTetO) promoter with a LacZ reporter gene (NIPP1*-LacZ) were used. The NIPP1* fragment is a truncated version of an endogenous form of NIPP1, which includes a nuclear localization signal and a PP1 inhibition domain, but excludes all other endogenous NIPP1 functional domains. To obtain double transgenic animals, these mice were crossed with mice expressing a reverse tetracycline-controlled transactivator (rtTA2) under the control of the forebrain-specific CaMKII $\alpha$ promoter (Michalon et al. 2005). Mice were maintained in accordance with the Federation of Swiss Cantonal Veterinary Office and INSERM committee or European Community Council Directive (86/609/EEC) guidelines.

To induce transgene expression, mice were treated with dox for at least $8 \mathrm{~d}$ (Westward Pharmaceuticals) as previously described (Michalon et al. 2005). For on/off experiments, mice were treated with dox for at least $8 \mathrm{~d}$, then dox was withdrawn and mice were tested at least $7 \mathrm{~d}$ later. For all experiments, adult (3-8 mo-old) NIPP1*-LacZ transgenic males (carrying both transgenes and fed with dox) and control littermates (carrying no transgene, one of the two transgenes, i.e., either NIPP1* or LacZ, fed with dox, or carrying both transgenes but not fed with dox) were used. 


\section{RT-PCR}

Total RNA was isolated with TRI Reagent (Research Center) and purified with Promega's RQ1 DNase, followed by precipitation with sodium acetate and ethanol. Reverse transcription was performed with $1 \mu \mathrm{g}$ of total RNA using an Enhanced Avian HS RT-PCR kit (Sigma).

\section{Protein phosphatase assay}

Protein phosphatase assays were carried out as previously described (Hedou et al. 2008). Hippocampi were dissected and homogenized in $3.75 \mathrm{mM}$ Tris- $\mathrm{HCl}$ ( $\mathrm{pH} 7.4), 15 \mathrm{mM} \mathrm{KCl}, 3.75$ $\mathrm{mM} \mathrm{NaCl}, 250 \mu \mathrm{M}$ EDTA, $50 \mu \mathrm{M}$ EGTA, 30\% (w/v) sucrose, 30\% (v/v) glycerol, protease inhibitor cocktail (Sigma), $100 \mu \mathrm{M}$ PMSF using a Dounce homogenizer, then centrifuged (1000g, $10 \mathrm{~min}$ ). Supernatant (cytoplasmic fraction) and pellet (nuclear fraction) were separated. Each fraction was resuspended as above without sucrose but with $15 \mathrm{mM} \beta$-Mercaptoethanol, homogenized, and purified on PiResin (Innova Biosciences). Phosphatase activity was determined by incubating a $2-\mu \mathrm{g}$ sample with $0.15 \mathrm{mM}$ RII substrate (BIOMOL) and $5 \mathrm{nM}$ tautomycin (to inhibit PP1) or 5 $\mathrm{nM}$ tautomycin+okadaic acid (OA) (to inhibit PP1 and PP2A activity) in $50 \mathrm{mM}$ Tris- $\mathrm{HCl}\left(\mathrm{pH}\right.$ 7.0), $100 \mu \mathrm{M} \mathrm{Na}{ }_{2}$ EDTA, $5 \mathrm{mM}$ DTT, $0.01 \%$ Brij35 at $30^{\circ} \mathrm{C}$ for $10 \mathrm{~min}$. The amount of free phosphates released was measured with BIOMOL Green reagent (BIOMOL) at $620 \mathrm{~nm}$ and background subtracted. For total phosphatase activity, tautomycin and OA were removed from the reaction. PP1 and PP2A activity was calculated by the ratio of phosphatase activity to inhibitors and total phosphatase activity.

\section{Immunohistochemistry}

Free-floating sections of fixed brains from transcardially perfused $(0.9 \% \mathrm{NaCl}$, followed by $4 \%$ formaldehyde $/ 1 \%$ glutaraldehyde in $\mathrm{PBS}$ at $\mathrm{pH}$ 7.4) animals were incubated with neuronal nuclear antigen (NeuN; $1: 500 ;$ Sigma) and $\beta$-galactosidase ( $\beta$-gal; 1:1000; Sigma), followed by Cy3 goat anti-rabbit and fluorescein isothiocyanate (FITC)-donkey anti-mouse (1:500; Jackson ImmunoResearch Laboratories). Nuclear staining was performed using 4'-6-Diamidino-2-phenylindole (DAPI) or hematoxylin. Organotypic hippocampal slices were double immunostained for $\beta$-gal expression and NeuN (neuronal nuclear antigen). Slices were fixed overnight at $4{ }^{\circ} \mathrm{C}$ in $4 \%$ paraformaldehyde in $0.1 \mathrm{M}$ phosphate buffer $(\mathrm{PB})$ at $\mathrm{pH} 7.4$, washed in $0.1 \mathrm{M} \mathrm{PB}(3 \times 1 \mathrm{~h})$, then blocked and permeabilized in $0.1 \mathrm{M} \mathrm{PB}, 0.4 \%$ Triton $\mathrm{X}-100$, and $10 \%$ heat-inactivated horse serum for $24 \mathrm{~h}$ at $4{ }^{\circ} \mathrm{C}$. Slices were incubated in primary antibodies against green fluorescent protein (GFP) (1:1000, rabbit, Synaptic Systems) and NeuN (1:1000, mouse, Chemicon) for $72 \mathrm{~h}$ at $4{ }^{\circ} \mathrm{C}$ in $0.1 \mathrm{M} \mathrm{PB}, 0.4 \%$ Triton X-100, and $10 \%$ horse serum, followed by overnight incubation with goat anti-rabbit FITC and donkey anti-mouse tetramethyl rhodamine isothiocyanate (TRITC) fluorescence-conjugated secondary antibodies (1:1000, Jackson ImmunoResearch). All images were acquired with a CoolSNAP digital camera (Roper Scientific) and an Axiophot microscope (Zeiss) and analyzed using MCID Elite 7.0 software (MCID).

\section{Behavior}

The water maze training was conducted as previously described (Malleret et al. 2001). During training, mice were allowed to swim until they reached the hidden platform or for a maximum of $90 \mathrm{sec}$. They were then placed manually on the platform for $15 \mathrm{sec}$. On the day of testing, $24 \mathrm{~h}$ after training, mice were put in the water for $60 \mathrm{sec}$ and their search for the platform was recorded using a video tracking system (Viewpoint). Fear conditioning was performed as described (Koshibu et al. 2005).

\section{In vitro electrophysiology}

Mice were anesthetized in isofluorane or halothane and decapitated; their brains were removed and immersed in fresh ice-cold aCSF gassed with $95 \% \mathrm{O}_{2}$ and $5 \% \mathrm{CO}_{2}$. Acute slices were prepared with a vibratome, transferred to a submerged chamber $\left(34^{\circ} \mathrm{C}, 40\right.$ $\mathrm{min}$ ), and then incubated at room temperature for $1 \mathrm{~h}$. For recording, test stimulus intensity was set to evoke $30 \%-50 \%$ of the maximum f-EPSP. Recorded signals were amplified with an AXOPATCH 200B amplifier (Axon Instruments/Molecular Devices) and sampled using pCLAMP. For dentate gyrus recordings, aCSF contained $124 \mathrm{mM} \mathrm{NaCl}, 1.5 \mathrm{mM} \mathrm{MgSO}_{4}, 1.2 \mathrm{mM}$ $\mathrm{NaH}_{2} \mathrm{PO}_{4}, 3.5 \mathrm{mM} \mathrm{KCl}, 2.5 \mathrm{mM} \mathrm{CaCl}, 26.2 \mathrm{mM} \mathrm{NaHCO}$, $11 \mathrm{mM}$ D-glucose; for hippocampus recordings: $119 \mathrm{mM} \mathrm{NaCl}$, $1.3 \mathrm{mM} \mathrm{MgCl}_{2} .6 \mathrm{H}_{2} \mathrm{O}, 1.3 \mathrm{mM} \mathrm{NaH} \mathrm{PO}_{4}, 2.5 \mathrm{mM} \mathrm{KCl}, 2.5 \mathrm{mM}$ $\mathrm{CaCl}_{2}, 26 \mathrm{mM} \mathrm{NaHCO}_{3}, 11 \mathrm{mM}$ D-glucose saturated with $95 \% \mathrm{O}_{2} / 5 \% \mathrm{CO}_{2}$. Acute slices were sagittal for area CA1 and coronal for dentate gyrus $400-\mu \mathrm{m}$ thick. For dentate gyrus, bipolar tungsten electrodes were used for stimulation, and 2-6 $\mathrm{M} \Omega$ glass micropipettes were filled with $2 \mathrm{M} \mathrm{NaCl}$ for recording. Stimulation and recording electrodes were placed in the middle one-third of the dentate gyrus molecular layer $(500 \mu \mathrm{m}$ apart) and recordings were performed in the presence of $50 \mu \mathrm{M}$ bicuculline methiodide (Sigma). For area CA1, borosilicate electrodes filled with aCSF were placed in Schaffer collaterals for stimulation and stratum radiatum for recording. For assays on gene transcription, slices were preincubated with $25 \mu \mathrm{M}$ actinomycin D for at least $2 \mathrm{~h}$ before recording.

\section{DNA microarray analyses}

Total RNA was extracted using the NucleoSpin Kit II (Macherey-Nagel) and quality controlled using Agilent's RNA Nano Kit and Bioanalyzer 2100. Next, 600 ng of total RNA was amplified and fluorescently labeled following Agilent's "OneColor Microarray-Based Gene Expression Analysis." cRNA was purified using Qiagen's RNeasy Mini Kit and the dye incorporation measured using a NanoDrop ND-1000 UV-VIS Spectrophotometer. cRNA yield and Cy3 incorporation needed to be higher than $1.65 \mu \mathrm{g}$ and $9 \mathrm{pmol} / \mu \mathrm{g}$ cRNA, respectively, to be processed further. Cy3-labeled samples were hybridized onto Agilent's Whole Mouse Genome Oligo microarrays $(1 \times 44 \mathrm{~K}$ format) following the manufacturer's instructions. The following day, arrays were scanned using standard settings on Agilent's DNA microarray scanner and raw expression data extracted using Agilent's Feature Extraction Software 9.1. The preprocessed data was then imported into GeneSpring 7.3, median normalized, filtered on expression level in all samples (5 NIPP1*-LacZ, 4 control), and analyzed using ANOVA and the Benjamini and Hochberg false discovery rate for multiple testing corrections (Benjamini and Hochberg 1995). Genes were considered differentially expressed when $P<0.05$ and fold change was $P>1.2$, based on recommendations from the Microarray Quality Control Comparison project (Guo et al. 2006; Shi et al. 2006). The false discovery rate was 0.14 , which is comparable to that reported in recent analyses in the brain (Renthal et al. 2007). Ingenuity pathway analysis was used to group genes into functional classes (www.ingenuity.com).

\section{Quantitative RT-PCR}

Quantitative RT-PCR was performed as described (Koshibu et al. 2009). Each sample was quantified three times for each run. A comparative Ct method was used to assess differences in gene expression between samples (Livak and Schmittgen 2001). $\beta$-actin was used as internal control.

\section{Transcription factor binding site analysis}

Analysis of the $5^{\prime}$-upstream region of differentially expressed genes for putative transcription factor binding sites was conducted as described elsewhere (Levenson et al. 2004). In brief, 1000-bp upstream of the transcription start site of each gene was used to search for transcription factor binding sites using MatInspector software (Cartharius et al. 2005). As a control for false-positives, putative binding sites present in the upstream region of the housekeeping genes GAPDH, $\beta$-actin, and $\beta$-tubulin were not taken into account. 


\section{Statistics}

ANOVAs and univariate or multivariate general linearized models (GLM) were used to determine genotype and treatment effect. Tukey's or LSD post-hoc analyses were conducted when appropriate. Statistical significance was set at $P \leq 0.05\left({ }^{*}\right), P \leq 0.01\left(^{* *}\right)$, and $P \leq 0.001\left(^{(* *}\right)$. All values are expressed as mean \pm SEM.

\section{Acknowledgements}

We thank Holger Russig, Hans-Rüdi Olpe, Christine Gee, and Hansjörg Kasper for technical support, Andrea Patrignani and Hubert Rehauer for help with the microarray analysis, Mélanie Kollen for help with the electrophysiology, Gregor Fischer for help with the mouse colony, Lubka Spassova-Boos for genotyping, and Roland Schöb and Eva Hochreutener (sadly deceased while this manuscript was completed) for help with the figures. The laboratory of I.M.M. is supported by the University of Zürich, the Swiss Federal Institute of Technology, the Swiss National Science Foundation, the National Center for Competence in Research "Neural Plasticity and Repair," the Human Frontier Science Program, EMBO, and the Novartis Research Foundation.

\section{References}

Alberini CM. 2009. Transcription factors in long-term memory and synaptic plasticity. Physiol Rev 89: 121-145.

Aonurm-Helm A, Zharkovsky T, Jurgenson M, Kalda A, Zharkovsky A. 2008 Dysregulated CREB signaling pathway in the brain of neural cell adhesion molecule (NCAM)-deficient mice. Brain Res 1243: 104-112.

Benjamini Y, Hochberg Y. 1995. Controlling the false discovery rate-a practical and powerful approach to multiple testing. I R Statist Soc B 57: 289-300.

Bennett D. 2005. Transcriptional control by chromosome-associated protein phosphatase-1. Biochem Soc Trans 33: 1444-1446.

Bingol B, Schuman EM. 2005. Synaptic protein degradation by the ubiquitin proteasome system. Curr Opin Neurobiol 15: 536-541.

Bollen M, Beullens M. 2002. Signaling by protein phosphatases in the nucleus. Trends Cell Biol 12: 138-145.

Buttner B, Kannicht C, Reutter W, Horstkorte R. 2005. Novel cytosolic binding partners of the neural cell adhesion molecule: Mapping the binding domains of PLC $\gamma$, LANP, TOAD-64, syndapin, PP1, and PP2A. Biochemistry 44: 6938-6947.

Cartharius K, Frech K, Grote K, Klocke B, Haltmeier M, Klingenhoff A Frisch M, Bayerlein M, Werner T. 2005. MatInspector and beyond: Promoter analysis based on transcription factor binding sites. Bioinformatics 21: 2933-2942.

Cavallaro S, D'Agata V, Manickam P, Dufour F, Alkon DL. 2002. Memory-specific temporal profiles of gene expression in the hippocampus. Proc Natl Acad Sci 99: 16279-16284.

Ceulemans H, Bollen M. 2004. Functional diversity of protein phosphatase-1, a cellular economizer and reset button. Physiol Rev 84: $1-39$.

Chen A, Muzzio IA, Malleret G, Bartsch D, Verbitsky M, Pavlidis P, Yonan AL, Vronskaya S, Grody MB, Cepeda I, et al. 2003. Inducible enhancement of memory storage and synaptic plasticity in transgenic mice expressing an inhibitor of ATF4 (CREB-2) and C/EBP proteins. Neuron 39: 655-669.

Cohen S, Greenberg ME. 2008. Communication between the synapse and the nucleus in neuronal development, plasticity, and disease. Annu Rev Cell Dev Biol 24: 183-209.

D'Agata V, Cavallaro S. 2003. Hippocampal gene expression profiles in passive avoidance conditioning. Eur J Neurosci 18: 2835-2841.

D'Agata V, Warren ST, Zhao W, Torre ER, Alkon DL, Cavallaro S. 2002. Gene expression profiles in a transgenic animal model of fragile $\mathrm{X}$ syndrome. Neurobiol Dis 10: 211-218.

Davis HP, Squire LR. 1984. Protein synthesis and memory: A review. Psychol Bull 96: 518-559.

Dhavan R, Tsai LH. 2001. A decade of CDK5. Nat Rev Mol Cell Biol 2: 749-759.

Doherty P, Fazeli MS, Walsh FS. 1995. The neural cell adhesion molecule and synaptic plasticity. J Neurobiol 26: 437-446.

Fischer A, Sananbenesi F, Schrick C, Spiess J, Radulovic J. 2003. Regulation of contextual fear conditioning by baseline and inducible septohippocampal cyclin-dependent kinase 5. Neuropharmacology 44: 1089-1099.

Fonseca R, Vabulas RM, Hartl FU, Bonhoeffer T, Nagerl UV. 2006. A balance of protein synthesis and proteasome-dependent degradation determines the maintenance of LTP. Neuron 52: 239-245.
Genoux D, Haditsch U, Knobloch M, Michalon A, Storm D, Mansuy IM. 2002. Protein phosphatase 1 is a molecular constraint on learning and memory. Nature 418: 970-975.

Goelet P, Castellucci VF, Schacher S, Kandel ER. 1986. The long and the short of long-term memory-a molecular framework. Nature 322: $419-422$.

Guan ZH, Giustetto M, Lomvardas S, Kim JH, Miniaci MC, Schwartz JH, Thanos D, Kandel ER. 2002. Integration of long-term-memory-related synaptic plasticity involves bidirectional regulation of gene expression and chromatin structure. Cell 111: 483-493.

Guo L, Lobenhofer EK, Wang C, Shippy R, Harris SC, Zhang L, Mei N, Chen T, Herman D, Goodsaid FM, et al. 2006. Rat toxicogenomic study reveals analytical consistency across microarray platforms. Nat Biotechnol 24: 1162-1169.

Hata R, Masumura M, Akatsu H, Li F, Fujita H, Nagai Y, Yamamoto T, Okada H, Kosaka K, Sakanaka M, et al. 2001. Up-regulation of calcineurin A $\beta$ mRNA in the Alzheimer's disease brain: Assessment by cDNA microarray. Biochem Biophys Res Commun 284: $310-316$.

Hedou G, Mansuy IM. 2003. Inducible molecular switches for the study of long-term potentiation. Philos Trans R Soc Lond B Biol Sci 358: 797-804.

Hedou GF, Koshibu K, Farinelli M, Kilic E, Gee CE, Kilic U, Baumgartel K, Hermann DM, Mansuy IM. 2008. Protein phosphatase 1-dependent bidirectional synaptic plasticity controls ischemic recovery in the adult brain. J Neurosci 28: $154-162$.

Hu XD, Huang Q, Yang X, Xia H. 2007. Differential regulation of AMPA receptor trafficking by neurabin-targeted synaptic protein phosphatase-1 in synaptic transmission and long-term depression in hippocampus. J Neurosci 27: 4674-4686.

Huang YY, Kandel ER. 1994. Recruitment of long-lasting and protein kinase A-dependent long-term potentiation in the CA1 region of hippocampus requires repeated tetanization. Learn Mem 1: 74-82.

Ishimaru N, Tabuchi A, Hara D, Hayashi H, Sugimoto T, Yasuhara M, Shiota J, Tsuda M. 2007. Regulation of neurotrophin-3 gene transcription by Sp3 and Sp4 in neurons. J Neurochem 100: $520-531$.

Jagiello I, Van Eynde A, Vulsteke V, Beullens M, Boudrez A, Keppens S, Stalmans W, Bollen M. 2000. Nuclear and subnuclear targeting sequences of the protein phosphatase-1 regulator NIPP1. J Cell Sci 113: $3761-3768$

Jones MW, Errington ML, French PJ, Fine A, Bliss TVP, Garel S, Charnay P, Bozon B, Laroche S, Davis S. 2001. A requirement for the immediate early gene Zif268 in the expression of late LTP and long-term memories. Nat Neurosci 4: 289-296.

Jouvenceau A, Hedou G, Potier B, Kollen M, Dutar P, Mansuy IM. 2006. Partial inhibition of PP1 alters bidirectional synaptic plasticity in the hippocampus. Eur J Neurosci 24: 564-572.

Kaltschmidt B, Ndiaye D, Korte M, Pothion S, Arbibe L, Prullage M, Pfeiffer J, Lindecke A, Staiger V, Israel A, et al. 2006. NF-кB regulates spatial memory formation and synaptic plasticity through protein kinase A/CREB signaling. Mol Cell Biol 26: 2936-2946.

Kandel ER. 2001. The molecular biology of memory storage: A dialogue between genes and synapses. Science 294: 1030-1038.

Kandel ER, Schwartz JH. 1982. Molecular biology of learning: Modulation of transmitter release. Science 218: 433-443.

Koshibu K, Ahrens ET, Levitt P. 2005. Postpubertal sex differentiation of forebrain structures and functions depend on transforming growth factor- $\alpha$. J Neurosci 25: 3870-3880.

Koshibu K, Gräff J, Beullens M, Heitz FD, Berchtold D, Russig H, Farinelli M, Bollen M, Mansuy IM. 2009. Protein phosphatase 1 regulates the histone code for long-term memory. J Neurosci 29: 13079-13089.

Lee YS, Silva AJ. 2009. The molecular and cellular biology of enhanced cognition. Nat Rev Neurosci 10: 126-140.

Levenson JM, Choi S, Lee SY, Cao YA, Ahn HJ, Worley KC, Pizzi M, Liou HC, Sweatt JD. 2004. A bioinformatics analysis of memory consolidation reveals involvement of the transcription factor c-rel. J Neurosci 24: 3933-3943.

Lisman J. 1989. A mechanism for the Hebb and the anti-Hebb processes underlying learning and memory. Proc Natl Acad Sci 86: 9574-9578

Livak KJ, Schmittgen TD. 2001. Analysis of relative gene expression data using real-time quantitative PCR and the $2^{-\Delta \Delta C T}$ method. Methods 25: 402-408.

Ma L, Song L, Radoi GE, Harrison NL. 2004. Transcriptional regulation of the mouse gene encoding the $\alpha-4$ subunit of the $\mathrm{GABA}_{\mathrm{A}}$ receptor. J Biol Chem 279: 40451-40461.

Malleret G, Haditsch U, Genoux D, Jones MW, Bliss TV, Vanhoose AM Weitlauf C, Kandel ER, Winder DG, Mansuy IM. 2001. Inducible and reversible enhancement of learning, memory, and longterm potentiation by genetic inhibition of calcineurin. Cell 104: 675-686. 
Mansuy IM, Shenolikar S. 2006. Protein serine/threonine phosphatases in neuronal plasticity and disorders of learning and memory. Trends Neurosci 29: 679-686.

Martin SJ, Grimwood PD, Morris RG. 2000. Synaptic plasticity and memory: An evaluation of the hypothesis. Annu Rev Neurosci 23: $649-711$.

Mayford M, Bach ME, Huang YY, Wang L, Hawkins RD, Kandel ER. 1996. Control of memory formation through regulated expression of a CaMKII transgene. Science 274: 1678-1683.

Michalon A, Koshibu K, Baumgartel K, Spirig DH, Mansuy IM. 2005. Inducible and neuron-specific gene expression in the adult mouse brain with the rtTA2S-M2 system. Genesis 43: 205-212.

Moorhead GB, Trinkle-Mulcahy L, Ulke-Lemee A. 2007. Emerging roles of nuclear protein phosphatases. Nat Rev Mol Cell Biol 8: $234-244$.

Morishita W, Connor JH, Xia H, Quinlan EM, Shenolikar S, Malenka RC. 2001 . Regulation of synaptic strength by protein phosphatase 1 . Neuron 32: $1133-1148$.

Morris RGM, Moser EI, Riedel G, Martin SJ, Sandin J, Day M, O'Carroll C. 2003. Elements of a neurobiological theory of the hippocampus: The role of activity-dependent synaptic plasticity in memory. Philos Trans $R$ Soc Lond B Biol Sci 358: 773-786.

Munton RP, Vizi S, Mansuy IM. 2004. The role of protein phosphatase-1 in a modulation of synaptic and structural plasticity. FEBS Letters 567: $121-128$.

Paulsen O, Moser EI. 1998. A model of hippocampal memory encoding and retrieval: GABAergic control of synaptic plasticity. Trends Neurosci 21: $273-278$.

Ramos B, Gaudilliere B, Bonni A, Gill G. 2007. Transcription factor Sp4 regulates dendritic patterning during cerebellar maturation. Proc Natl Acad Sci 104: 9882-9887.

Renthal W, Maze I, Krishnan V, Covington HE III, Xiao G, Kumar A, Russo SJ, Graham A, Tsankova N, Kippin TE, et al. 2007. Histone deacetylase 5 epigenetically controls behavioral adaptations to chronic emotional stimuli. Neuron 56: 517-529.

Renthal W, Kumar A, Xiao G, Wilkinson M, Covington HE III, Maze I, Sikder D, Robison AJ, LaPlant Q, Dietz DM, et al. 2009. Genome-wide analysis of chromatin regulation by cocaine reveals a role for sirtuins. Neuron 62: $335-348$.

Shi L, Reid LH, Jones WD, Shippy R, Warrington JA, Baker SC, Collins PJ, de Longueville F, Kawasaki ES, Lee KY, et al. 2006. The MicroArray Quality Control (MAQC) project shows inter- and intraplatform reproducibility of gene expression measurements. Nat Biotechnol 24: 1151-1161.

States BA, Khatri L, Ziff EB. 2008. Stable synaptic retention of serine-880-phosphorylated GluR2 in hippocampal neurons. Mol Cell Neurosci 38: 189-202.

Stork O, Welzl H. 1999. Memory formation and the regulation of gene expression. Cell Mol Life Sci 55: 575-592.

Terry-Lorenzo RT, Roadcap DW, Otsuka T, Blanpied TA, Zamorano PL, Garner CC, Shenolikar S, Ehlers MD. 2005. Neurabin/protein phosphatase-1 complex regulates dendritic spine morphogenesis and maturation. Mol Biol Cell 16: 2349-2362.

Venero C, Tilling T, Hermans-Borgmeyer I, Schmidt R, Schachner M, Sandi C. 2002. Chronic stress induces opposite changes in the mRNA expression of the cell adhesion molecules NCAM and L1. Neuroscience 115: $1211-1219$.

Virshup DM, Shenolikar S. 2009. From promiscuity to precision: Protein phosphatases get a makeover. Mol Cell 33: 537-545.

Wang JH, Kelly PT. 1996. The balance between postsynaptic $\mathrm{Ca}^{2+}$ dependent protein kinase and phosphatase activities controlling synaptic strength. Learn Mem 3: 170-181.

Welzl H, Stork O. 2003. Cell adhesion molecules: Key players in memory consolidation? News Physiol Sci 18: 147-150.

Zhou X, Long JM, Geyer MA, Masliah E, Kelsoe JR, Wynshaw-Boris A, Chien KR. 2005. Reduced expression of the Sp4 gene in mice causes deficits in sensorimotor gating and memory associated with hippocampal vacuolization. Mol Psychiatry 10: 393-406.

Zhou X, Qyang Y, Kelsoe JR, Masliah E, Geyer MA. 2007. Impaired postnatal development of hippocampal dentate gyrus in Sp4 null mutant mice. Genes Brain Behav 6: 269-276.

Received January 31, 2010; accepted in revised form April 29, 2010. 


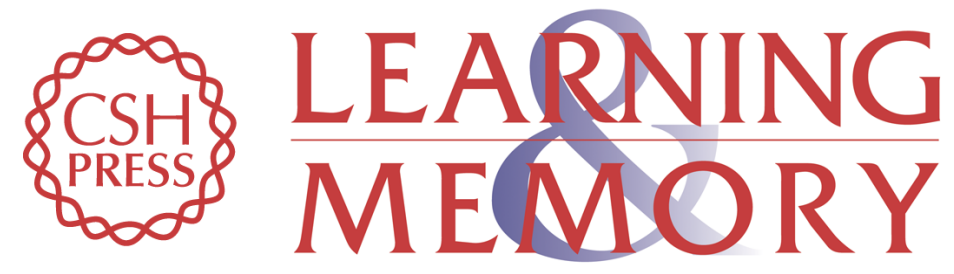

\section{Protein phosphatase 1-dependent transcriptional programs for long-term memory and plasticity}

Johannes Gräff, Kyoko Koshibu, Anne Jouvenceau, et al.

Learn. Mem. 2010, 17:

Access the most recent version at doi:10.1101//m.1766510 Supplemental
Material http://learnmem.cshlp.org/content/suppl/2010/06/30/17.7.355.DC1

References This article cites 65 articles, 17 of which can be accessed free at: http://learnmem.cshlp.org/content/17/7/355.full.html\#ref-list-1

License

Email Alerting Receive free email alerts when new articles cite this article - sign up in the box at the Service top right corner of the article or click here. 